\title{
FALLING FROM HEIGHT: AN INTERESTING UNUSUAL PATTERN OF INJURIES
}

\author{
Mona S EIGohary, Enas I. Elmadah, Amira A. Wahdan \\ Department of Forensic Medicine and Clinical Toxicology, Faculty of Medicine, Tanta \\ University
}

\begin{abstract}
Introduction: Falling from height is considered a major public health problem being the second leading cause of unintentional injury death, after road traffic injuries. Falling represents a specific type of blunt force trauma, which is produced by rapid vertical deceleration and impact. There is no adequate literature available with reference to the type and pattern of injuries sustained in cases of falling from heights.

Aim of the work: The aim of the present study was to analyze the different patterns of injuries sustained in victims of falling from different heights looking for recording possible uncommon patterns of injuries and to detect the incidence of substance abuse among them.

Patients and methods: This study is a cross sectional statistical study of 200 cases of falling from different heights presented to Alkasr Alainy Emergency department during a period of six months from July to December 2013. Data collected included age, gender, occupation, circumstances of fall, height of falling, nature of landing surface, site and type of injuries sustained due to falling, besides calculation of injury severity score (ISS) for each case. In addition; urine dipstick test for detection of drugs of abuse was done for each case using the commercial kit (Abon Biopharm, Hangzhou, China).

Results: Half of the cases fell from heights of one meter or less. Except for the three suicidal cases, the rest of the cases fell from height accidentally. The distribution of injuries took one of two forms; injuries in combined multiple sites of the body or injuries in isolated body region (uncommon pattern of injuries in cases of falling from height). At a height of one meter or less (low level), more than half of the cases had their injuries in the extremities while in higher heights, injuries were in combined multiple sites of the body. Blunt force wounds of the skin \& subcutaneous tissue were the most common types of injuries in all cases. Urine dipstick test was positive in 21.5 $\%$ of cases. Only tramadol and cannabis were detected.

Conclusion: It was concluded that falling from low heights is a very common phenomenon with its resultant injuries especially in the extremities. Injuries in isolated body region are not uncommon in cases of falling from height and represent one of the medicolegal challenges. External blunt force wounds were the most common type of injuries due to falling. In addition substance abuse is among the factors leading to falling from height.
\end{abstract}

Key words: falling, height, pattern, injuries, substance abuse.

\section{INTRODUCTION}

A fall is defined as an event in which a person inadvertently comes to the ground, floor or other lower level
(Mirza, et al., 2013 ). Globally, falls are a major public health problem. An estimated 424000 fatal falls occur each year, making it the second leading 
cause of unintentional injury death, after road traffic injuries. Over $80 \%$ of fall-related fatalities occur in low- and middle-income countries (WHO, 2012).

Falling is a multifactorial phenomenon. Risk factors could be categorized into intrinsic and extrinsic factors. Gender, muscular weakness, balance and gait impairment, sensory deficits, chronic diseases, depression, cognitive impairment, and age more than 80 years constitute intrinsic risk factors. Among extrinsic risk factors, drug abuse, alcohol overuse, ignorance of safety principles seem to be the most important ones (Jamebozorgi, et al., 2013).

Falling from a height represent a specific type of blunt force trauma, which is produced by rapid vertical deceleration and impact forces ( $\mathbf{L i}$ and Smialek, 1994). The occurrence of falling could be accidental, intentional (suicide attempt or homicide) or as a result of psychiatric illness and use of drugs (Osifo, et al., 2010). In forensic practice, it is difficult to decide whether the death resulted due to falling is from an accident, suicide or homicide, particularly in the absence of an eye witness, suicidal notes or other indications suggesting suicide or homicide. It is considered one of the dilemmas in forensic case works. History of mental disorders with previous attempts at suicide is the likely explanation of suicide but not a conclusive proof (Mirza, et al., 2013 ).

The characteristics of injuries and their outcomes depend on several factors; the height of falling, the landing position of the body, the surface onto which the victim falls, age, and comorbidities of the patient (Lapostolle, et al., 2005) .
There is no adequate literature available with reference to the type and pattern of injuries sustained in cases of falling from heights (Prathapan and Umadethan, 2015). Therefore the aim of the present study was to analyze the different patterns of injuries sustained in victims of falling from different heights looking for recording possible uncommon patterns of injuries and to detect the incidence of substance abuse among them that could be one of the leading causes of falling from height.

\section{PATIENTS AND METHODS}

This study is a cross sectional statistical study of 200 cases of traumas of various degrees of severity associated with falling from height presented to Alkasr Alainy Emergency department during a period of six months from July to December 2013 after obtaining an informed written consent for participation from each patient or from one of his first degree relatives. Patients suffering traumas associated with vague history and children below 18 years were excluded.

Data collected included age, gender, occupation, circumstances of falling, height of falling, the nature of landing surface, the site and type of injuries sustained due to falling. The injury severity score (ISS) was calculated for each case to assess the severity of injuries. The ISS was described as the sum of the squares of the highest Abbreviated Injury Scale (AIS) grade in each of the three most severely injured body regions (head/neck, face, thorax, abdomen, extremities, and external) with possible values ranging from 1 to 75 . The patient with an AIS of 6 was automatically assigned an ISS value of 75 , which was associated with almost 
certain mortality. The ISS value and the three AIS used in its calculation do not contain information about the location and nature of the patient's injuries (Samin and Civil, 1999). The AIS is an anatomical scoring system first introduced in 1969. Injuries are ranked on a scale of 1 to 6 , with 1 being minor, 2 moderate, 3 serious, 4 severe, 5 critical and 6 an un-survivable injury (Brohi, 2007). Urine dipstick test for detection of drugs of abuse was done using the commercial kit, Abon Biopharm, Hangzhou, China. This one step multi-drug, multi-line screen test device is an immunoassay based on the principle of competitive binding. This test was used for detection of the following drugs: amphetamine, barbiturates, benzodiazepines, buprenorphine, cocaine, marijuana, methadone, methadone metabolite, methamphetamine, morphine, methylenedioxy-methamphetamine, opiate, oxycodone, phencyclidine, propoxphene, tramadol \& fontanel.

The collected data were organized and statistically analyzed using SPSS software statistical computer package version 22. For quantitative data, the median and interquartile range were calculated. For comparison between groups in quantitative data, MannWhitney $U$ and Kruskal Wallis tests were used as indicated. For qualitative data, comparison between two or more groups was done using Chi-square, Cochran's Q or Fisher Exact tests as indicated. Significance was adopted at $p \leq 0.05$ for interpretation of results of tests (Dawson-Saunders and Trapp, 2001).

\section{RESULTS}

A total of 200 cases were included. Their ages ranged between 18 and 76 years with a median of 26 years. Most of them were below the age of 40 years (77\%). There were 160 males and 40 females making a male to female ratio of $4: 1$ (table 1 )

About the half of cases included in this study fell from heights of one meter or less. Falls occurred accidentally in all cases except three who tried to commit suicide by jumping from heights. Suicidal attempts took place from heights of 5, 9 and 13 meters. Eighty four percent of victims fell on hard surface as asphalt, ceramic or irregular hard surface in construction sites (table 2).

The injury severity score (ISS) ranged between 1 and 66 with a median of 4. The median ISS was 4, 5, 5 and 19 at one meter or less, >1meter to 5 meters, $>5$ meter to 10 meters and $>10$ meters respectively, with significant difference between the four groups ( $\mathrm{p}$ value $\leq 0.05$ ).

In $46 \%$ of cases, injuries were present in combined multiple sites of the body. In the remaining 54\%, injuries were present in one region of the body. The extremities were the most commonly involved region $(38.5 \%)$ followed by head and neck region $(8 \%)$, then the chest and the abdomen (3.5\% each). The pelvis was the least common involved region $(0.5 \%)$.

When falls occurred from a height of one meter or less (low level), more than half of the cases had their injuries in the extremities while in higher heights, injuries were mainly in combined multiple sites of the body (table 3).

Extremity injuries were present in 180 cases $(90 \%)$ either alone in 77 cases $(38.5 \%)$ or in combination with multisite injuries (103 cases, 51.5\%). The most frequent type of injuries was 
blunt force wounds of skin and subcutaneous tissue of the extremities (78 cases), followed by ankle sprain (59 cases). Both occurred mainly at low heights (one meter or less) with significant difference between the four groups, while lower limb bones fractures occurred more commonly with higher heights again with significant difference between the four groups ( $p$ value $\leq 0.05$ ) (table 4 ).

Head \& neck injuries were present in 93 cases $(46.5 \%)$ either alone in 16 cases $(8 \%)$ or in combination with multisite injuries (77 cases, 38.5\%). The most frequent type was blunt force wounds of scalp and subgalia (in 46 cases) and the least common was cerebral contusion (in 2 cases). The blunt force wounds and concussion occurred more commonly at low heights, while fractures and intracranial hemorrhage occurred more commonly at higher heights. Cerebral contusion occurred only at height more than 10 meters. The differences were significant between the four groups as regards these types of injuries ( $p$ value $\leq 0.05$ ) (table 5)

Chest injuries were present in 69 cases $(34.5 \%)$ either alone in 7 cases $(3.5 \%)$ or in combination with multisite injuries (62 cases, 31\%). The most common type of injuries was blunt force wounds of skin, subcutaneous tissue and muscles of the chest area (27 cases), followed by rib fractures (in 18 cases), then hemothorax (in 8 cases), pneumothorax (in 7 cases), lung contusion (in 4 cases) and the least common type was sternal fracture (in 4 cases). It was observed that all these types of injuries were randomly distributed with different heights except for rib fractures which occurred mainly with higher heights with significant difference between the four groups ( $\mathrm{p}$ value $\leq 0.05$ )

Abdominal injuries were present in 32 cases (16\%) either alone in 7 cases $(3.5 \%)$ or as in combination with multisite injuries (25 cases, $12.5 \%$ ). The most frequent type of injuries was blunt force wounds of skin, subcutaneous tissue and muscles of the abdominal area (16 cases), followed by splenic injuries and intra-abdominal free fluid ( 6 cases for each of them) and the least common injuries were lumbar fracture and retroperitoneal fluid collection (in 2 cases for each of them). All these injuries occurred more commonly in high heights except for lumbar fracture which occurred equally in low and high heights. The differences were significant between the four groups as regards the blunt force wounds and the intra-abdominal free fluid ( $\mathrm{p}$ value $\leq 0.05$ ).

Pelvic injuries were present in 23 cases $(11.5 \%)$ either alone in 1 case $(0.5 \%)$ or in combination with multisite injuries (22 patients, 11\%). The most frequent type of injuries was pelvic fracture (13 cases), then urinary bladder injuries (6 cases), blunt force wounds of skin, subcutaneous tissue and muscles of the pelvic area (3 cases) and the least common was sacral fracture (one case). All these types of injuries were randomly distributed with different heights except for sacral fracture which occurred only at height more than 10 meters. The difference was significant between the four groups as regards the pelvic fractures only ( $p$ value $\leq 0.05$ ).

Urine dipstick test was positive in 43 cases $(21.5 \%)$. Among them, 39 cases $(90.7 \%$ of them) were positive for tramadol and 4 cases were positive for cannabis. Thirty cases $(69.8 \%$ of them) 
were manual workers, two were engineers, one was physician and ten patients were working in other occupations. The three suicidal cases included in this study were positive for tramadol.

Nine $(20.9 \%)$ of the cases with positive urine dipstick test fell from low heights (one meter or less) and the remaining $79.1 \%$ fell from higher heights while in cases with negative urine dipstick test, $59.2 \%$ fell from low heights and the remaining $40.8 \%$ fell from higher heights

Table (1): Demographic characteristics of the studied cases

\begin{tabular}{|c|c|c|c|}
\hline & & $\mathrm{n}^{*}$ & $\%$ \\
\hline \multirow[t]{4}{*}{ Age groups } & $18-<40$ years & 154 & $77 \%$ \\
\hline & $40-<60$ years & 39 & $19.5 \%$ \\
\hline & $\geq 60$ years & 7 & $3.5 \%$ \\
\hline & Total & 200 & $100 \%$ \\
\hline \multirow[t]{3}{*}{ Sex } & Male & 160 & $80 \%$ \\
\hline & Female & 40 & $20 \%$ \\
\hline & Total & 200 & $100 \%$ \\
\hline \multirow[t]{7}{*}{ Occupation } & Manual workers & 100 & $50 \%$ \\
\hline & House wives & 25 & $12.5 \%$ \\
\hline & Engineers & 3 & $1.5 \%$ \\
\hline & Physician & 2 & $1 \%$ \\
\hline & Other occupations & 64 & $32 \%$ \\
\hline & Retired & 6 & $3 \%$ \\
\hline & Total & 200 & $100 \%$ \\
\hline
\end{tabular}

"n= number

Table (2): Circumstances of falling, falling height and nature of landing surface in studied cases

\begin{tabular}{|c|c|c|c|}
\hline & & $\mathrm{n}^{*}$ & $\%$ \\
\hline Circumstances & Suicidal & 3 & $1.5 \%$ \\
\hline & Homicidal & 0 & $0 \%$ \\
\hline & Accidental & 197 & $98.5 \%$ \\
\hline & Total & 200 & $100 \%$ \\
\hline Falling height & $\leq 1$ meter & 102 & $51 \%$ \\
\hline & $>1$ meter - 5 meters & 31 & $15.5 \%$ \\
\hline & $>5$ meter - 10meters & 40 & $20 \%$ \\
\hline & $>10$ meter & 27 & $13.5 \%$ \\
\hline & Total & 200 & $100 \%$ \\
\hline $\begin{array}{l}\text { Nature of } \\
\text { landing surface }\end{array}$ & $\begin{array}{l}\text { Hard surface (asphalt ceramic or irregular } \\
\text { hard surface) }\end{array}$ & 168 & $84 \%$ \\
\hline & Soft surface (ramlah or agriculture surface) & 32 & $16 \%$ \\
\hline & Total & 200 & $100 \%$ \\
\hline
\end{tabular}

${ }^{*} \mathrm{n}=$ number 
Table (3): Correlation between height of falling and site of injuries

\begin{tabular}{|c|c|c|c|c|c|c|c|c|c|c|c|}
\hline & \multicolumn{8}{|c|}{ Height } & \multirow{2}{*}{\multicolumn{2}{|c|}{$\begin{array}{c}\text { Fisher's } \\
\text { exact test }\end{array}$}} \\
\hline & & \multicolumn{2}{|c|}{$\leq 1$ meter } & \multicolumn{2}{|c|}{$\begin{array}{c}>1 \text { meter - } \\
5 \text { meters }\end{array}$} & \multicolumn{2}{|c|}{$\begin{array}{l}>5 \text { meter - } \\
10 \text { meters }\end{array}$} & \multicolumn{2}{|c|}{$>10$ meter } & & \\
\hline & & $\mathrm{n}^{*}$ & $\%$ & $\mathrm{n}$ & $\%$ & $\mathrm{n}^{*}$ & $\%$ & $n^{*}$ & $\%$ & $X^{2}$ & $\mathrm{P}$ \\
\hline \multirow{7}{*}{$\begin{array}{l}\text { Site of } \\
\text { injurie } \\
S\end{array}$} & Head & 8 & $7.84 \%$ & 3 & $9.68 \%$ & 4 & $10 \%$ & 1 & $3.70 \%$ & \multirow{7}{*}{$\begin{array}{l}1.38 \\
9\end{array}$} & \multirow{7}{*}{$\begin{array}{l}0.24 \\
3\end{array}$} \\
\hline & Chest & 3 & $2.94 \%$ & 1 & $3.23 \%$ & 2 & $5 \%$ & 1 & $3.70 \%$ & & \\
\hline & Abdomen & 2 & $1.96 \%$ & 0 & $0 \%$ & 5 & $\begin{array}{l}12.5 \\
\%\end{array}$ & 0 & $0 \%$ & & \\
\hline & Pelvis & 0 & $0 \%$ & 0 & $0 \%$ & 1 & $2.5 \%$ & 0 & $0 \%$ & & \\
\hline & $\begin{array}{l}\text { Extremitie } \\
\text { S }\end{array}$ & 56 & $\begin{array}{l}54.90 \\
\%\end{array}$ & 8 & $\begin{array}{l}25.81 \\
\%\end{array}$ & $\begin{array}{l}1 \\
1\end{array}$ & $\begin{array}{l}27.5 \\
\%\end{array}$ & 2 & $7.41 \%$ & & \\
\hline & $\begin{array}{l}\text { Multiple } \\
\text { sites }\end{array}$ & 33 & $\begin{array}{l}32.35 \\
\%\end{array}$ & $\begin{array}{l}1 \\
9\end{array}$ & $\begin{array}{l}61.29 \\
\%\end{array}$ & $\begin{array}{l}1 \\
7\end{array}$ & $\begin{array}{l}42.5 \\
\%\end{array}$ & $\begin{array}{l}2 \\
3\end{array}$ & $\begin{array}{l}85.19 \\
\%\end{array}$ & & \\
\hline & Total & $\begin{array}{l}10 \\
2\end{array}$ & $100 \%$ & $\begin{array}{l}3 \\
1\end{array}$ & $100 \%$ & $\begin{array}{l}4 \\
0\end{array}$ & $100 \%$ & $\begin{array}{l}2 \\
7\end{array}$ & $100 \%$ & & \\
\hline
\end{tabular}

${ }^{*} \mathrm{n}=$ number

Table (4): Correlation between height of falling and types of injuries of the extremities

\begin{tabular}{|c|c|c|c|c|c|c|c|c|c|c|c|}
\hline & \multicolumn{8}{|c|}{ Height } & \multirow{3}{*}{$\begin{array}{c}\text { Total } \\
\mathbf{n}^{* *}\end{array}$} & \multirow{2}{*}{\multicolumn{2}{|c|}{$\begin{array}{c}\text { Fisher exact } \\
\text { test }\end{array}$}} \\
\hline & \multicolumn{2}{|c|}{$\leq 1$ meter } & \multicolumn{2}{|c|}{$\begin{array}{c}\text { >1meter - } 5 \\
\text { meters }\end{array}$} & \multicolumn{2}{|c|}{$\begin{array}{c}>\text { 5meter } \\
-10 \\
\text { meters }\end{array}$} & \multicolumn{2}{|c|}{ >10meter } & & & \\
\hline & $\mathbf{n}^{* *}$ & $\%$ & $\mathrm{n}^{* *}$ & $\%$ & $\mathbf{n}^{* *}$ & $\%$ & $\mathbf{n}^{* * *}$ & $\%$ & & $\mathbf{X}^{2}$ & $\mathbf{P}$ \\
\hline $\begin{array}{l}\text { Extremity } \\
\text { wound }\end{array}$ & 51 & $60.71 \%$ & 10 & $55.56 \%$ & 11 & $55 \%$ & 6 & $35.29 \%$ & 78 & 10.990 & $0.011 *$ \\
\hline $\begin{array}{l}\text { Clavicular } \\
\text { fracture }\end{array}$ & 0 & $0 \%$ & 0 & $0 \%$ & 1 & $5 \%$ & 2 & $11.76 \%$ & 3 & 6.462 & 0.420 \\
\hline $\begin{array}{l}\text { Humeral } \\
\text { fracture }\end{array}$ & 0 & $0 \%$ & 0 & $0 \%$ & 1 & $5 \%$ & 0 & $0 \%$ & 1 & 3.870 & 0.490 \\
\hline $\begin{array}{l}\text { Ulnar } \\
\text { fracture }\end{array}$ & 1 & $1.19 \%$ & 0 & $0 \%$ & 0 & $0 \%$ & 0 & $0 \%$ & 1 & 1.998 & 1.000 \\
\hline $\begin{array}{l}\text { Radial } \\
\text { fracture }\end{array}$ & 1 & $1.19 \%$ & 1 & $5.56 \%$ & 1 & $5 \%$ & 0 & $0 \%$ & 3 & 2.066 & 0.485 \\
\hline $\begin{array}{l}\text { Femoral } \\
\text { fracture }\end{array}$ & 0 & $0 \%$ & 0 & $0 \%$ & 0 & $0 \%$ & 1 & $5.88 \%$ & 1 & 4.656 & 0.135 \\
\hline $\begin{array}{l}\text { Tibial } \\
\text { fracture }\end{array}$ & 3 & $3.57 \%$ & 3 & $16.67 \%$ & 3 & $15 \%$ & 7 & $41.18 \%$ & 16 & 12.820 & $0.002 *$ \\
\hline $\begin{array}{l}\text { Fibular } \\
\text { fracture }\end{array}$ & 3 & $3.57 \%$ & 3 & $16.67 \%$ & 3 & $15 \%$ & 6 & $35.29 \%$ & 15 & 10.299 & $0.009 *$ \\
\hline $\begin{array}{l}\text { Ankle } \\
\text { sprain }\end{array}$ & 44 & $52.38 \%$ & 9 & $50 \%$ & 3 & $15 \%$ & 3 & $17.65 \%$ & 59 & 24.101 & $<0.001 *$ \\
\hline $\begin{array}{l}\text { Metatarsal } \\
\text { fracture }\end{array}$ & 2 & $2.38 \%$ & 0 & $0 \%$ & 1 & $5 \%$ & 0 & $0 \%$ & 3 & 1.090 & 1.000 \\
\hline Total & 105 & & 26 & & 24 & & 25 & & 180 & & \\
\hline
\end{tabular}

*statistically significant $(\mathrm{p} \leq 0.05)$

$* * \mathrm{n}=$ number 
Table (5): Correlation between height of falling and types of head injuries

\begin{tabular}{|c|c|c|c|c|c|c|c|c|c|c|c|}
\hline & \multicolumn{8}{|c|}{ Height } & \multirow{3}{*}{$\begin{array}{l}\text { Tota } \\
1 \\
n^{* * *}\end{array}$} & \multirow{2}{*}{\multicolumn{2}{|c|}{$\begin{array}{l}\text { Fisher's } \\
\text { exact Test }\end{array}$}} \\
\hline & \multicolumn{2}{|c|}{$\leq 1$ meter } & \multicolumn{2}{|c|}{$\begin{array}{l}>1 \text { meter - } \\
5 \text { meters }\end{array}$} & \multicolumn{2}{|c|}{$\begin{array}{l}>5 \text { meter - } \\
10 \text { meters }\end{array}$} & \multicolumn{2}{|c|}{$>10$ meter } & & & \\
\hline & $\mathbf{n}^{*}$ & $\%$ & $\mathbf{n}^{*}$ & $\%$ & $\mathbf{n}^{*}$ & $\%$ & $\mathbf{n}^{*}$ & $\%$ & & $\mathbf{X}^{2}$ & $\mathbf{P}$ \\
\hline $\begin{array}{l}\text { Head or } \\
\text { neck } \\
\text { wound }\end{array}$ & 15 & $\begin{array}{l}48.4 \\
\%\end{array}$ & 13 & $\begin{array}{l}68.4 \\
\%\end{array}$ & 10 & $\begin{array}{l}52.6 \\
\%\end{array}$ & 8 & $40 \%$ & 46 & $\begin{array}{l}10.99 \\
9\end{array}$ & $\begin{array}{l}0.011 \\
*\end{array}$ \\
\hline $\begin{array}{l}\text { Skull } \\
\text { fracture }\end{array}$ & 0 & $0 \%$ & 1 & $5.3 \%$ & 1 & $5.3 \%$ & 3 & $15 \%$ & 5 & 8.983 & $\begin{array}{l}0.012 \\
*\end{array}$ \\
\hline $\begin{array}{l}\text { Concussio } \\
\text { n }\end{array}$ & 16 & $\begin{array}{l}51.6 \\
\%\end{array}$ & 5 & $\begin{array}{l}26.3 \\
\%\end{array}$ & 7 & $\begin{array}{l}36.8 \\
\%\end{array}$ & 5 & $25 \%$ & 33 & 0.337 & 0.983 \\
\hline $\begin{array}{l}\text { Intracrani } \\
\text { al } \\
\text { hemorrha } \\
\text { ge }\end{array}$ & 0 & $0 \%$ & 1 & $5.3 \%$ & 1 & $5.3 \%$ & 2 & $10 \%$ & 4 & 6.540 & $\begin{array}{l}0.043 \\
*\end{array}$ \\
\hline $\begin{array}{l}\text { Cervical } \\
\text { fracture }\end{array}$ & 0 & $0 \%$ & 1 & $5.3 \%$ & 1 & $5.3 \%$ & 1 & $5 \%$ & 3 & 4.724 & 0.116 \\
\hline $\begin{array}{l}\text { Cerebral } \\
\text { contusion }\end{array}$ & 0 & $0 \%$ & 0 & $0 \%$ & 0 & $0 \%$ & 2 & $10 \%$ & 2 & 6.662 & $\begin{array}{l}0.018 \\
*\end{array}$ \\
\hline Total & 31 & & 21 & & 20 & & 21 & & 93 & & \\
\hline
\end{tabular}

*statistically significant $(\mathrm{p} \leq 0.05)$

$* * \mathrm{n}=$ number

\section{DISCUSSION}

Falling from height represent a traditional issue for forensic pathology (Casali, et al., 2014). Falling from height is a mechanism that can cause a wide variety of injuries, associated both with the direct impact on the surface and with the deceleration (Petaros, et al., 2013). The aim of the present study was to analyze the different patterns of injuries sustained in victims of falling from different heights looking for recording possible uncommon patterns of injuries and to detect the incidence of substance abuse among them.

In the present study a total of 200 cases were included. Their ages ranged between 18 and 76 years with a median of 26 years and most of them were below the age of 40 years $(77 \%)$. This was in partial agreement with Osifo, et al., (2010) from Nigeria who reported that the median age of their study cases was 24 years and $70 \%$ of them were below the age of 30 years. On the other hand Petaros, et al., (2013) found that the median age of the victims included in their study in Croatia was 55 years. Icer, et al., (2013) from Turkey reported that $48 \%$ of their cases were in the age group between 4-15 years. This difference could be attributed to the wide range of ages ( 1 month to 95 years) involved in their studies.

Eighty percent of patients included in the current study were males, making a male to female ratio of $4: 1$. These results went hand in hand with Grivna, et al., (2014) who reported that, $82 \%$ of their studied patients from United Arab Emirates were males \& $18 \%$ were females. Males were also more common than females in a study done by Icer, et al., (2013) who reported that male victims of falling from height accounted for $63.7 \%$ of their study. In our opinion this male preponderance could be explained on the basis that males are more exposed to occupational hazards, and stress or strain 
as compared to females.

In the current study, 50\% were manual workers. This could be due to lack of safety measures during work which makes the manual workers more susceptible for hazards of falling. In addition $12.5 \%$ were housewives and only 3\% were retired. These results disagreed with Chao, et al., (2000) from Singapore who found that $44 \%$ of their studied cases were retired or unemployed and $9 \%$ were housewives.

All cases included in this study fell from height accidentally except for three cases who tried to commit suicide by jumping from heights. This was in partial agreement with Goren, et al., (2003) from Turkey who reported that, $89 \%$ of their study cases were related to accidents while $11 \%$ were related to suicide attempts. On the other hand Lapostolle, et al., (2005) found that suicidal attempts accounted for $42.9 \%$, of their study which was done in France. The lower suicidal rate in the current study might be attributed to religious prohibition of the suicidal act among Egyptians.

Most of the cases included in the present study fell from a height of one meter or less $(51 \%)$, followed by $>1$ to 5 meters $(31 \%)$. This is because their falls occurred from high heel shoes, platform or from one or two staircases. This was similar to results obtained by Arbes and Berzlanovich, (2015) who reported that $55.2 \%$ of their study cases from Germany fell from same level ( 0 meters), $35.8 \%$ from less than 5 meters, and $9 \%$ from more than 5 meters. On the other hand Vasudeva Murthy, et al., (2012) concluded that in $48.07 \%$ of their cases the height of fall was $0-20$ feet (0- 6 meters) and in $40.38 \%$ it was $21-40$ feet (6-12 meters). Cases studied by Vasudeva Murthy et al., (2012) were fatal cases of falling from height from India subjected to autopsy examination so the height was more than that included in the present study.
In this study, falls occurred on hard surface more than on soft surface $(84 \%$ and $16 \%$ respectively). This was similar to Icer, et al., (2013) who found that $78.1 \%$ of falls occurred on hard surface \& $21.9 \%$ on soft surface. The high incidence of falls on hard surface in the present study may be attributed to the high number of manual workers (especially construction workers) who fell during their work on hard surface.

The ISS was recorded for all cases. It ranged between $1 \& 66$ with a median of 4 . These results were widely different from results obtained by Kent and Pearce, (2006) in their study in Australia. They found that the ISS ranged from 1 to 54 with a median of 26 . The low median of ISS recorded in the present study may be due to the high percentage of patients who fell from low level ( $\leq 1$ meter). A correlation between height of falling and the median of ISS was done. The median of ISS was found to increase with the increase in the height of falling. This result was similar to that obtained by AunonMartin, et al., (2012) who found a significant relationship between the height of falling and ISS. They recorded that it was not a linear relationship, but the higher the height of the falling, the higher the ISS and the lower the individual probability of survival.

In the current study, the distribution of injuries took one of two forms; injuries in combined multiple sites of the body (in $46 \%$ of cases) or injuries in isolated body region $(38.5 \%$ in extremities, $8 \%$ in head and neck, $3.5 \%$ in abdomen, $3.5 \%$ in chest and $0.5 \%$ in pelvis. Reference-wise it is very rare to find injuries in isolated body region (especially the abdomen and the chest) in cases of falling from height. Actually such cases represent one of the medicolegal challenges in assessing the cause of death particularly in absence of any data concerning crime scene investigations. It is widely believed that diagnosis of falling from height as a cause of death is associated with finding combined multiple site fatal injuries. To 
the best of our knowledge the study of Gupta, et al., (1982) from India is the only one which reported similar finding. The distribution of injuries in their study was also either in isolated body region (30\% in head, $1.7 \%$ in abdomen and $1.7 \%$ in the spine) or in multiple sites of the body (in $66.6 \%$ of cases).

In falls, the mechanical force that causes injuries is supplied by the movement of body itself. The counterforce in the first instance is provided by the inertia of the body and in the second instance it is provided by the rigidity of stationary object against which the body falls. At the moment of impact, a falling body undergoes deceleration and the amount of kinetic energy transferred to the ground reacts with an equal amount against the body itself. The energy lost is reabsorbed by the person himself in the form of injuries (Chao, et al., 2000). The injuries in isolated body region in the current study could be explained on the basis that nearly all the acquired kinetic energy from falling is consumed on the first impact region of the body that fell on a raised area of an irregular landing surface leaving no enough energy sufficient to induce secondary impact injuries.

In the present study, the most affected body region was the extremities (in $90 \%$ of the studied cases), followed by the head \& neck (in $46.5 \%$ ), the chest (in $34.5 \%$ ) then the abdomen (in 16\%) and the least affected region was the pelvis (in 11.5\%) of course after taking in consideration the overlapping frequencies. Similar results were reported by Grivna, et al., (2014) who found that the most common injured anatomical regions were the extremities $(70 \%)$, followed by the head\& neck $(18 \%)$, spine $(13 \%)$, chest $(13 \%)$ and abdomen $(4 \%)$. On the other hand, these results disagreed with Icer, et al., (2013) who reported that the most affected body part was the head (in 26.4\% of cases), followed by extremities (in $26.2 \%$ ), then abdomen (in 14.9\%) and the least affected was the chest (in 5.3\%). The high incidence of injuries in the extremities reported in the current study may be attributed to the high incidence of falls from low height ( $\leq 1$ meter) which lead to minor injuries usually in the extremities. This finding was clarified when a correlation between height of fall \& site of injuries sustained during fall was performed as it was found that at a height of one meter or less more than half of the cases sustained injuries in the extremities while in higher heights the injuries were mainly in combined multiple sites of the body.

Types of injuries that occurred due to falling were also analyzed. In the extremities, blunt force wounds of skin and subcutaneous tissue were the most frequent type of injuries (in 78 cases), followed by ankle sprain (in 59 cases). In the head\& neck region, the most frequent type of injuries was blunt force wounds of scalp and subgalia (in 46 cases), followed by concussion (in 33 cases). In thoracic region, the most common type of injuries was blunt force wounds of skin, subcutaneous tissue and muscles of the chest area (in 27cases), followed by rib fractures (in 18 cases). In addition in abdomen, blunt force wounds of skin, subcutaneous tissue and muscles were also the most frequent type of injuries (in 16 case), followed by intra-abdominal free fluid \& splenic injuries (in 6 cases for each). While in pelvis, the most frequent type of injuries was pelvic fractures (13 cases), followed by urinary bladder injuries (6 cases). The prevalence of the less severe blunt force wounds of skin and subcutaneous tissue found in this study in most of the affected body regions could be attributed to the fact that the severity of the injury is typically proportional to the fall height (McSwain and Shaftan, 1990) and in the current study most of the cases $(51 \%)$ fell from low heights ( $\leq 1$ meter). Against these results, Gupta, et al., (1982) found that in head, brain injuries with skull fracture were the most common injuries 
(in $58.7 \%$ ) followed by combination of different types of intracranial hemorrhage (in $36.5 \%$ ). In the chest region, fractures were the most common injuries (in 30.2\%) followed by lung injuries (in 28.6\%). In the abdominal region, liver injuries were the most frequent (in 22.2\%) followed by peritoneal hemorrhage (in 19\%). In addition, Icer, et al., (2013) found that in the head, cranial fractures occurred most frequently (in $19.14 \%$ of cases) followed by cerebral edema (in $7.9 \%$ ). In thoracic region, rib fractures were the most common (in 2.5\%), followed by pneumothorax (in 1.6\%). In the abdomen, intra-abdominal free fluid was the most frequent (in 14\%), followed by splenic injuries (in 2.6\%). Furthermore in the extremities, the most encountered injuries were fracture femur (in $7.9 \%$ ), then fracture fibula (in $7.1 \%$ ) and humeral fracture (in $5.2 \%$ ). The difference between results of the current study and the other studies is due to the difference in falling heights.

Substance abuse was detected by urine dipstick test in 43 patients $(21.5 \%$ of cases included in the present study). This was consistent with finding of Arbes and Berzlanovich, (2015) who reported that history of substance abuse was present in 34 cases out of 201 included in their study.

Among the positive urine dipstick cases in this study, 39 patients were positive for tramadol and 4 patients were positive for cannabis. This result is different from results obtained by Velmahos, et al., (1997) in USA. They found that, alcohol intoxication was detected in $14.4 \%$ of their cases, illicit drugs in $16 \%$ and combined alcohol and illicit drugs in $7.5 \%$. Abuse of tramadol is a serious problem in a number of African countries, including Egypt. In 2011 and 2012, Egypt witnessed an upsurge in trafficking of tramadol. While in 2011, total seizures of tramadol preparations amounted to 120 million tablets, about 320 million tramadol tablets were seized in the seaports of Alexandria, Damietta and Port Said in the first quarter of 2012. The preparations are smuggled to Egypt mainly from China and India (INCB, 2013).

Thirty cases $(69.8 \%$ of the positive urine dipstick cases) were manual workers, two were engineers, one was physician and ten patients were working in other occupations. This results is widely different from results obtained by ElSawy, et al., (2010) who found that, $26.5 \%$ of their study cases (done in Egypt) were unemployed, $25.6 \%$ were skilled workers and only $4.4 \%$ were manual workers.

Interestingly, the three suicidal cases included in this study were positive for tramadol. This went hand in hand with the warning of the FDA, (2010)) which stated that tramadol should not be prescribed to patients who are suicidal or addictionprone, and caution should be exercised in prescribing the medications to patients who use alcohol excessively, suffer from emotional disturbance or depression, or take tranquilizers or antidepressants.

It is important to highlight that there are certain limitations in the current study. First, the study was a time-limited research based on data from single center (Alkasr Alainy Emergency department), that may not adequately reflect the spectrum of injuries sustained. In addition, the study was restricted to the events at the emergency department and did not determine the final outcome of treatment by the various sub-specialties that continued the management. Therefore, final outcomes of severe injuries, such as death or paralysis, were not determined.

\section{CONCLUSION}

The highest incidence of injuries due to fall from height was in the young productive age group (18- 40 years) with male preponderance as they are more exposed to occupational hazards. Manual workers were among the highest risk groups of fall from 
height especially in the absence of safety measures. Falling from low heights is a very common phenomenon with its resultant injuries especially in the extremities. Injuries in isolated body region (as the extremities, the head \& neck, the chest, the abdomen or the pelvis) are not uncommon in cases of falling from height and represent one of the medicolegal challenges. The most common types of injuries in cases included in this study were blunt force wounds of the skin \& subcutaneous tissue. Substance abuse was among the important factors of fall from height especially in manual workers.

\section{RECOMMENDATIONS}

1. Further studies based on data from multiple medical centers and including larger scale of victims with follow up of the final outcome should be done to cover all patterns of injuries and to determine the mortality rates in these cases.

2. Regular toxicological screening for manual workers and learning them the side effects of addiction.

\section{ACKNOWLEDGEMENT}

Thanks to Dr. Yasmin S. Elkholy, resident of Emergency Medicine in Alkasr Alainy Emergency department for her great help and cooperation in the collection of data included in this study

\section{REFERENCE}

Arbes, S. and Berzlanovich, A. (2015):

"Injury Pattern in Correlation with the Height of Fatal Falls". Wien Klin Wochenschr 127: 57- 61

Aunon-Martin, I., Doussoux, P. C., Baltasar, J. L., Polentinos-Castro, E., Mazzini, J. P. and Erasun, C. R. (2012): "Correlation between Pattern and Mechanism of Injury of Free Fall". Strategies Trauma Limb Reconstr 7: 141- 145

Brohi, K. (2007): "Abbreviated Injury
Scale

(Ais)

Score".

http://www.trauma.org/index.php/ma in/article/510/

Casali, M. B., Battistini, A., Blandino, A. and Cattaneo, C. (2014): "The Injury Pattern in Fatal Suicidal Falls from a Height: An Examination of 307 Cases". Forensic Sci Int 244: $57-$ 62

Chao, T. C., Lau, G. and Teo, C. E. (2000): "Fall from Height: The Pathology of Trauma from Vertical Deceleration". In: Pathology of Trauma, 3rd edition, Mason, J. K. and Purdue, B. N. (editor), Arnold, London. Pp:313- 326

Dawson-Saunders, B. and Trapp, R. (2001): "Basic and Clinical Biostatics", 3rd edition, DawsonSaunders, B. and Trapp, R. (editor), McGrow Hill McGrow Hill Medical Publishing Division

El-Sawy, H., Abdel Hay, M. and Badawy, A. (2010): "Gender Differences in Risks and Pattern of Drug Abuse in Egypt". Egypt J Neurol Psychiat Neurosurg 47: 413418

FDA (2010): "Ultram (Tramadol Hydrochloride), Ultracet (Tramadol Hydrochloride/Acetaminophen):

Label

Change". http://www.fda.gov/Safety/MedWatc h/SafetyInformation/SafetyAlertsfor HumanMedicalProducts/ucm213264 .htm

Goren, S., Subasi, M., Tyrasci, Y. and Gurkan, F. (2003): "Fatal Falls from Heights in and around Diyarbakir, Turkey". Forensic Sci Int 137: 37- 40

Grivna, M., Eid, H. O. and Abu-Zidan, F. M. (2014): "Epidemiology, Morbidity and Mortality from FallRelated Injuries in the United Arab Emirates". Scand J Trauma Resusc Emerg Med 22: 51-55

Gupta, S. M., Chandra, J. and Dogra, T. D. (1982): "Blunt Force Lesions Related to the Heights of a Fall". Am 
J Forensic Med Pathol 3: 35- 43

Icer, M., Guloglu, C., Orak, M. and Ustundag, M. (2013): "Factors Affecting Mortality Caused by Falls from Height". Ulus Travma Acil Cerrahi Derg 19: 529- 535

INCB (2013): "Report of the International Narcotics Control Board for 2012.". United Nations, New York. http://www.incb.org/documents/Publ ications/AnnualReports/AR2012/AR _2012_E_Chapter_III_Africa.pdf

Jamebozorgi, A. A., Kavoosi, A., Shafiee, Z., Kahlaee, A. H. and Raei, M. (2013): "Investigation of the Prevalent Fall-Related Risk Factors of Fractures in Elderly Referred to Tehran Hospitals". Med J Islam Repub Iran 27: 23- 30

Kent, A. and Pearce, A. (2006): "Review of Morbidity and Mortality Associated with Falls from Heights among Patients Presenting to a Major Trauma Centre". Emerg Med Australas 18: 23- 30

Lapostolle, F., Gere, C., Borron, S. W., Petrovic, T., Dallemagne, F., Beruben, A., Lapandry, C. and Adnet, F. (2005): "Prognostic Factors in Victims of Falls from Height". Crit Care Med 33: 12391242

Li, L. and Smialek, J. E. (1994): "The Investigation of Fatal Falls and Jumps from Heights in Maryland (1987-1992)". Am J Forensic Med Pathol 15: 295- 299

McSwain, N. E. and Shaftan, G. W. (1990): "Blunt Trauma after Vertical Deceleration". Postgrad Surg 2: 140145

Mirza, F. H., Parhyar, H. A., Tirmizi, S. Z. and Waheed, A. (2013):
"Fatalities of Fall Injuries in Karachia Five Year Autopsy Based Study". Medical Chanel 19: 53- 58

Osifo, O. D., Iribhogbe, P. and IdiodiThomas, H. (2010): "Falls from Heights: Epidemiology and Pattern of Injury at the Accident and Emergency Centre of the University of Benin Teaching Hospital". Injury 41: 544- 547

Petaros, A., Slaus, M., Coklo, M., Sosa, I., Cengija, M. and Bosnar, A. (2013): "Retrospective Analysis of Free-Fall Fractures with Regard to Height and Cause of Fall". Forensic Sci Int 226: 290- 295

Prathapan, V. and Umadethan, B. (2015): "Fall from Heights - Pattern of Injuries". Int $\mathrm{J}$ of Biomed Res 6: 8- 13

Samin, O. A. and Civil, I. D. (1999): "The New Injury Severity Score Versus the Injury Severity Score in Predicting Patient Outcome: A Comparative Evaluation on Trauma Service Patients of the Auckland Hospital". Annu Proc Assoc Adv Automot Med. 43: 1- 15

Vasudeva Murthy, C. R., Harish, S. and Girish Chandra, Y. P. (2012 ): "The Study of Pattern of Injuries in Fatal Cases of Fall from Height". Al Ameen J Med Sci 5: 45- 52

Velmahos, G. C., Demetriades, D., Theodorou, D., Cornwell, E. E., Belzberg, H., Asensio, J., Murray, J. and Berne, T. V. (1997): "Patterns of Injury in Victims of Urban Free-Falls". World J Surg 21: 816- 821

WHO (2012): "Fact Sheet N³44". http://www.who.int/mediacentre/fact sheets/fs344/en/ 
الملغص العربي

\section{السقوط من علو: نمط إصابات غير معتاد و مثير للاهتمام \\ منى سيد أحمد الجوهري و إيناس إبراهيم المداح و أميرة أمين وهدان

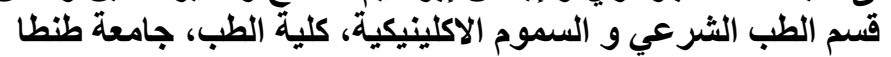

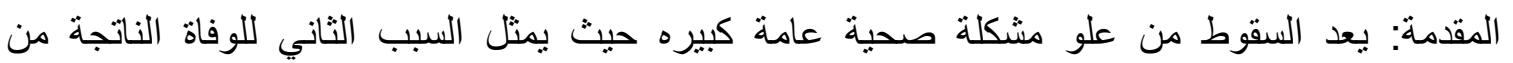

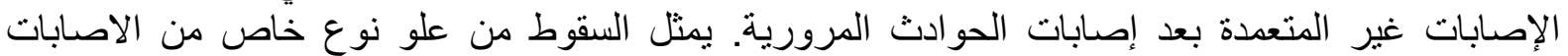

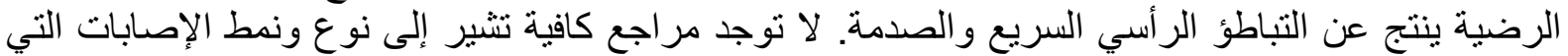

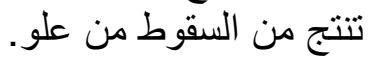

الهدف من الدراسة: اجريت هذه الدراسة لتحليل نمط الإصابات التي لحقت بضحايا السقوط من ارتفاعات

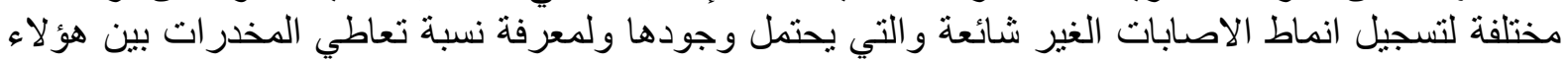
الضحايا.

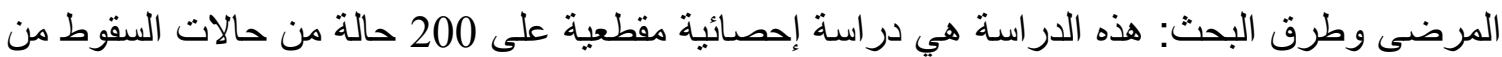

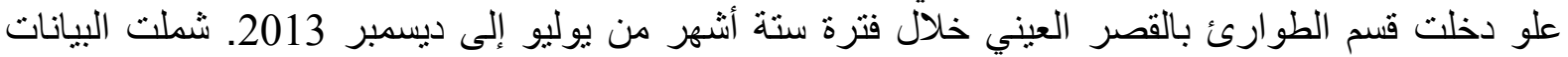

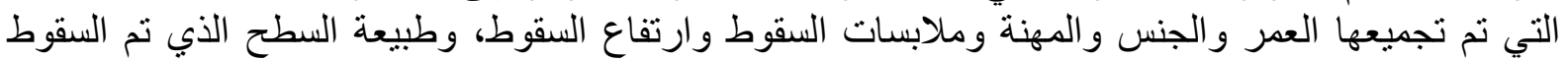

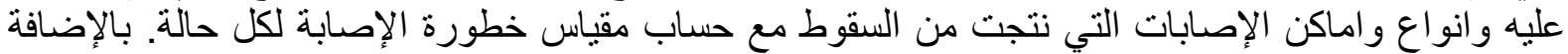
الى ذلك تم عمل اختبار للكثف عن تعاطي المخدرات في البول لكن لكل حالة باستخدام التحاليل التجارية.

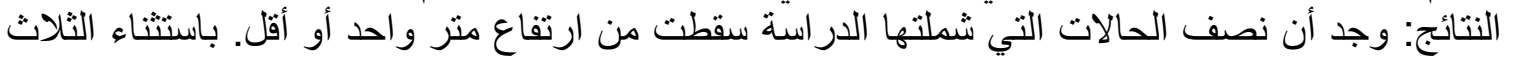

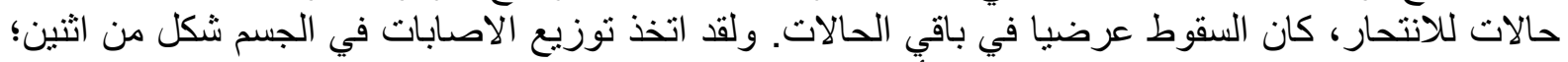

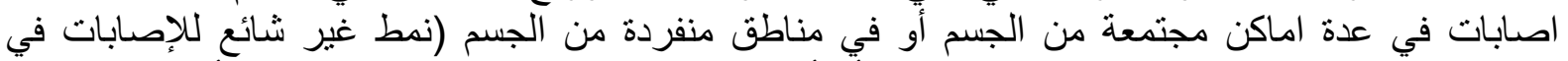

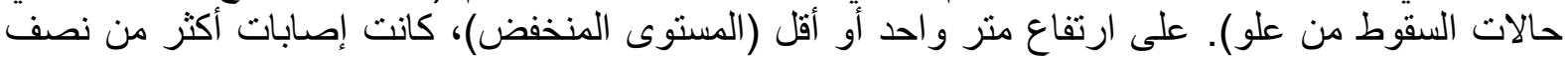

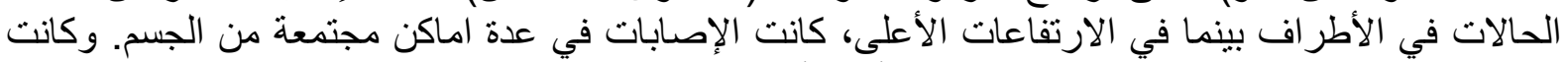

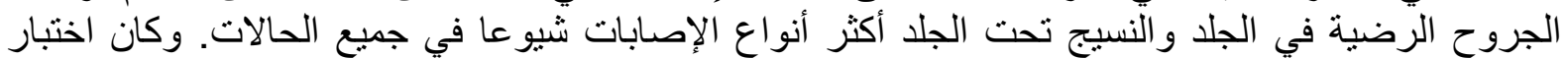

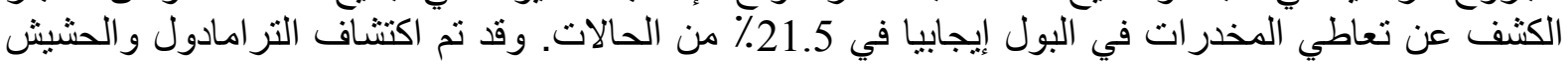

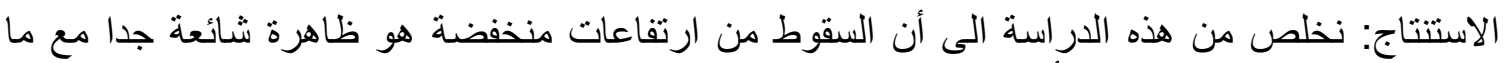

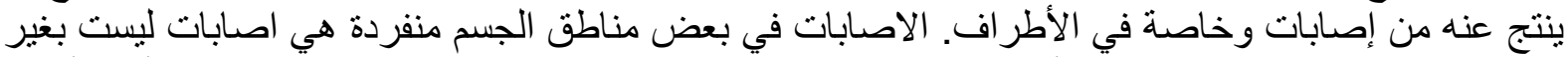

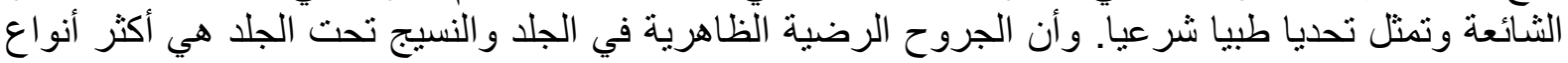

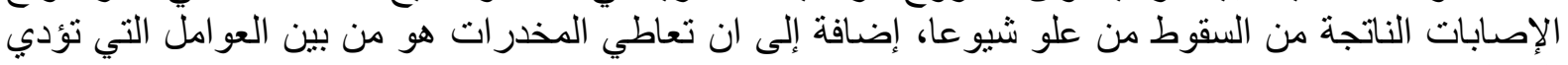
إلى السقوط من علو. 